\title{
THE OXIPO GAME COLLECTION FOR DEVELOPING COGNITIVE ABILITIES
}

Authors:

Katalin Mező (PhD)

University of Debrecen, Hungary

Ferenc Mező (PhD)

University of Eszterhazy, Hungary

E-mail address of first author:

mezo.katalin@ped.unideb.hu

\section{Lectors:}

Magdolna Nemes (PhD)

University of Debrecen

Lajos Kelemen (PhD)

Poliforma Kft.

Mező, K. \& Mező, F. (2020). The OxIPO Game Collection for Developing Cognitive Abilities. Különleges Bánásmód, 6. (1). 63-73. DOI 10.18458/KB.2020.1.63

\begin{abstract}
This study is a presentation of the first phase of a complex research project which aims to present the theoretical background of a new game collection (based on OxIPO model). We have compiled a game collection to improve cognitive abilities in early childhood. Concerning cognitive abilities, Affolter's (1972), Sindelar's (1994) and others' earlier developmental approaches took into account visual, auditive or motoric (inter) modalities of perception, however, we believe we need a more complex model to cover the full capability. Within the framework of the OxIPO model (Mezó, 2002, 2016), learning is interpreted as an information processing process. In the OxIPO model (Field, 2002, 2016), Learning = Organization $x$ (Input + Process + Output) allows us to control and systemize not only the input modalities but also the output modalities and also to interpret some cognitive abilities in the process phase. We have created a game-collection based on six input (visual, auditive, kinesthetic, olfactory, gustatory, and tactile) modalities and five cognitive abilities (perception, attention, memory, conceptual thinking, problem-solving thinking) and three output (visual, auditive, motoric) modalities. The outcome of the six input modalities and the five target abilities and the three output modalities there are 90 different games that can be described by the OxIPO model. In the future, we would like to prove with empirical studies that this game collection can be used for testing and developing 90 independent cognitive abilities. On the other hand, we need to prove that these cognitive abilities indeed influence the daily lives of children and their effectiveness.
\end{abstract}

Keywords: OxIPO model, ability, development, learning, game.

Disciplines: pedagogy, psychology 


\section{Absztrakt AZ OXIPO JÁTÉKGYÚJTEMÉNY A KOGNITÍV KÉPESSÉGEK FEJLESZTÉSÉÉRT}

Jelen tanulmány egy komplex kutatási projekt első szakaszának bemutatásáról szól, melynek célja egy új (az OxIPO modell alapján kidolgozott) játékgyújtemény elméleti hátterének megismertetése. A játékgyújtemény a gyermekkorban kialakuló kognitív képességek fejlesztése érdekében került összeállításra. A kognitív képességekkel kapcsolatban Affolter (1972), Sindelar (1994) és mások korábbi fejlesztési megközelítései figyelembe vették az érzékelés vizuális, auditív vagy motorikus (inter) modalitásait, de úgy gondoljuk, hogy komplexebb modellre van szükségünk a teljes képességrendszer lefedéséhez. Az OxIPO modell (Mező, 2002, 2016) keretén belül a tanulást információfeldolgozási folyamatként értelmezzük. Az OxIPO modellben (Mezó, 2002, 2016) a Tanulás = Organizáció - szervezés x (Input -bemenet + Process feldolgozás + Output- kimenet), ennek segítségével nem csak a bemeneti modalitásokat tudjuk szabályozni és rendszerezni, hanem a kimeneti modalitásokat is, és emellett értelmezhetünk néhány kognitív képességet a folyamatfázisban. Készítettünk egy játékgyújteményt, amely hat bemeneti (vizuális, auditív, kinesztikus, szaglás, ízléses és tapintható) modalitáson, öt kognitív képességen (észlelés, figyelem, memória, fogalmi gondolkodás, problémamegoldó gondolkodás) és három kimeneti (vizuális, auditív, motorikus) modalitáson alapul. A 6 bemeneti modalitás, az 5 célképesség és a 3 kimeneti modalitás eredményeként 90 különféle játék létezik, amelyeket az OxIPO modell leírhat. A jövőben empirikus vizsgálatokkal be kell bizonyítanunk, hogy ez a játékgyújtemény 90 független kognitív képesség tesztelésére és fejlesztésére használható. Másrészt be kell bizonyítanunk, hogy ezek a kognitív képességek valóban befolyásolják a gyermekek mindennapi életét és az eredményességüket.

Kulcsszavak: OxIPO modell, képesség, fejlesztés, tanulás, játék.

Diszciplínák: pedagógia, pszichológia

\section{What do we consider a development game?}

Development game is a practice (or series of practices) that is used to develop cognitive or noncognitive personality variables or skills (in the form of a game to arouse and maintain motivation during practice). This definition's justification is summarized in the following table (Table 1).

It is the best to follow some principles when applying development games. Here you can find the 10 principles of applying development games:

1. The principle of playfulness. The core activity of developing lessons should be the game. On the one hand, this is necessary to look from the aspect of characteristics of 0-10 age group (playcentric) and, on the other hand, to create the motivational base for the occupations.

2. The principle of interactivity. If a development game is used in a group, then it is a must to make available to connect with peers, to communicate, and to develop social skills in general. It is also possible during the group development, but in the individual development position it is the only way to shape the social skills and competences in the intergenerational (adult educator and the child, student) relation. The essence is that the participants do master the rules of adaptation and behavior during the game. 
Table 1. The explanation of the definition of the development game. (By the Authors)

\begin{tabular}{|c|c|}
\hline Text excerpt & Explanation \\
\hline $\begin{array}{l}\text { The development game is a } \\
\text { practice... }\end{array}$ & $\begin{array}{l}\text { The developer game practices something (ability, skill, role, etc.) - and therefore we } \\
\text { can also use the practice phrase for it. The term "development game" may some- } \\
\text { times refer to a separate practice, but we can use this concept for a complex set of } \\
\text { exercises built on one another. }\end{array}$ \\
\hline $\begin{array}{l}\ldots \text { that is used for cognitive or } \\
\text { non-cognitive personality var- } \\
\text { iables ... }\end{array}$ & $\begin{array}{l}\text { Cognitive personality variables include: perception, detection, attention, memory, } \\
\text { imagination, thinking. Non-cognitive personality variables include: anxiety, extra- } \\
\text { version, aggression, etc }\end{array}$ \\
\hline $\begin{array}{l}\ldots \text { or some kind of } \\
\text { skill ... }\end{array}$ & $\begin{array}{l}\text { Skill: Performance-driven, practiced set of actions with concrete content using ca- } \\
\text { pabilities and abilities that do not require constant thinking control when imple- } \\
\text { menting our actions. For example, speaking skills, reading, writing, counting, etc. }\end{array}$ \\
\hline ...we aim to develop... & $\begin{array}{l}\text { The development game (at least from the perspective of the developer pedagogue, } \\
\text { which may not be the identical with the child's or learner's point of view) is not a } \\
\text { self-destined activity, or an action done only for the sake of the game, but a prac- } \\
\text { tice (set of practices) for achieving a definite development goal. The goal of devel- } \\
\text { opment games - not being mutually exclusive (according to Kovács and Pálfi, } \\
\text { 2015): a) catalysing child development and stimulating development; (b) overcom- } \\
\text { ing, compensating and eliminating disadvantages; c) strengthening or developing } \\
\text { the elements of positive self-image; (d) reducing and eliminating developmental } \\
\text { dissynchronisation; (e) achieve the transfer effect of the game in other activities. }\end{array}$ \\
\hline $\begin{array}{l}\text {... (for forming and maintain- } \\
\text { ing motivation achieved by } \\
\text { practice in a game's form). }\end{array}$ & $\begin{array}{l}\text { The purpose of gamification of practices is to make - sometimes in itself - monot- } \\
\text { onous, exhausting, or perhaps uninteresting (as a result of the high number of rep- } \\
\text { etitions) practices interesting and attractive for children and students. Exercises } \\
\text { may also be used in non-gaming form, if required by the developing person. }\end{array}$ \\
\hline
\end{tabular}

3. Principle of establishing a partner relationship. The success of a developing session is greatly influenced by the success of creating such a trustful, partner-based atmosphere during the games. RogerTriassic: Empathy, unconditional acceptance, and credibility are crucially important to the developer teacher (and is ideal, if the child or student also adopts these values). The management of the sessions is the task of the developer teacher (it is go- od, if the player feels it), but it is reasonable to involve the player in the decisions as much as possible. For example, the rules the players set up themselves are tend to be more accepted by the participants than those that are forced on them.

4. Principle of ensuring positive self-image. The developer should select the game (especially the closing session) so that the child's positive image 
becomes stronger. It is advisable to use the following "sandwich model" for games designed for one occupation: after the first exercise that brings absolute success (encouraging), the more challenging games will come, and the last game will be a guaranteed success again (leaving a positive impression). The developer pedagogue should emphasize the learner's strengths, positive points, evolution signs and evidences in front of the child, learner and the social environment (family, educators, contemporaries) that are important to him!

5. The principle of preferring multifunctional games. If there are multiple games available to achieve the same goal, it is advisable to select a suitable game for the most purpose (e.g. to develop perception, attention, memory, etc. at the same time), as opposed to a game used to develop specifically one particular mental function. An exception is, if we are only interested in the functionality of a specific function due to diagnostic/development purposes. It should be noted, however, that basic mental functions are not independent. Therefore, we cannot talk about a practice that only requires attention because what requires attention that lso needs the control processes of perception, detection, memory, and thinking. For example, in classical observation-examination procedures in a given time given characters (say "a" letters) should be striked through in a task sheet filled with symbols (all sorts of letters). In addition to attention, it is also needed to detect and perceive signals, to understand and remember the task, etc.

6. Principle of using a three-level target system. There may be a three-level target system for applying development games. These:

- Mission: the goal that needs to be achieved by the end of the development process (for example, development of monotony tolerance) by using different exercises and games.

- Direct goal: the goal of a child, learner in the game is (for example, "Sort out the blue and red cards").
- Indirect goal: this is the goal why the developer has selected the particular task (for example: examining ability to distinguish between red and blue colors, and investigating / developing attention in case of a monotone task). This is not a secret to the player, but not sure if he is interested or understands.

\section{The pursuit of harmony between personal orientation} and goal orientation: the purpose of development can usually achieved in a variety of ways, through multiple games. The developer educator should strive to choose a game that takes into account the characteristics of the given child and learner (such as their level of development and interest) while respecting the development goal. This, of course, requires a wide-ranging methodological repertoire and/or game-creator competence.

8. Principle of process nature. As skill development is process-like, it is also necessary for player development. A gaming (or non-gaming) practice will only have ability-enhancing effects, if there is a chance for the child to frequently practice it - on a daily or at least weekly basis. We can not wait any development effect from an approx. 1-30 minutes long game. However, after 2-6 months of practice there is a chance of measurable and / or visible development.

9. Variety principle. The purpose of involving of games into development is to make the lessons more motivate him to participate in the sessions. At the same time - with varying tendencies per enjoyable for the child / student and thus child some games may no longer be attractive to him (or not even appealing at first try). At this point, the task of teacher is to play other games or game variants, which help to achieve the goal (mission) defined in the development plan. For example: it may happen that the classic paper-pencils tasks of development of attention may no longer motivate the child, but games that have the same ability but 
which require high-motion performance can give it new impulse.

10. Structural principle. The methodological game steps of developing games (Kovácsné and Pálfi, 2015) also reflect the general structure of games:

- Tuning. In the case of a known game, this recalls previous experience of the game, reconciling the previous and the current course of the game, and distributing props and roles. In the case of a new game, it is advisable to play a test game after inroducing of the game's rules, roleses and accessories. Tuning can happen by introducing a frame story (even from week to week) - see: Mező és Mező, 2013.

- The process of the game. In doing so, the role of the teacher may be: participant, game master, "fan". In order to maintain motivation, it is possible to incorporate new elements into the game's replay.

- Deduction, finish of the game. In doing so, the task of the developer teacher is to highlight and feedback the child's positive aspects, to initiate a voluntary conversation about the game's experience, to introduce the continuation of play and the game or to prepare and tune the child for the next game.

\section{Based on the OXIPO model} the main cornerstones of ability development

The OxIPO-model of learning according to the OxIPO-model (built on a cognitive psychology basis), learning is an information processing procedure, and has four components: input, process, output and organizing (Mező, 2002, 2011; Figure 1). Every component is built on the basis of special abilities, motivations, and methods.

Based on the OxIPO model, three development programs have been developed. These are the following:
Figure 1. The OxIPO-model (by Mezó,2002,2011)

$$
\begin{gathered}
\text { Learning }= \\
\text { Organization } \mathbf{x}(\text { Input }+ \text { Process }+ \text { Output })
\end{gathered}
$$

- OxIPO-Minimum Program (Mező, 2002, 2011) (formerly known as IPOO-Minimum Program)

- OxIPO personality- and behavior-forming toolkit (Mező, 2016)

- OxIPO Learning Skill Game Pack (The present study concerns the latter)

\section{Integrated diagnostics in ability development based on the OxIPO Model}

While diagnostics are an inseparable part of development, in practice it is not necessarily the task of the developer. This problem can be remedied by skill development developed under the OxIPO model, if development and diagnostics are not separate, but the development game also provides (it may not be standardized, but from a particular child it is accessible only and exclusively by the developer pedagogue, and therefore unique) diagnostic information. The games used in the OxIPO model are therefore primarily intended for development, but a diagnostic practice can use for development, and a development practice can use for diagnostics, too.

\section{The appearance of the OXIPO model in development games}

The input component of the OxIPO model in development games. Input (= the information that the player perceives during the game. Typical input: the referee's instructions) modalities (of sensory channel) include: 
- visual: the information seen

- auditive: the information heard

- kinesthetic: information on movement

- olfactoric: the fragrance information

- gustatory: tasteful information

- tactile: the perception and detection of tactile information

- multisensory

The process component of the OxIPO model in development games. OxIPO ability developing games are organized around the process phase of information processing and promote the ability (e.g. attention, memory, etc.) indicated there. Although a game can develop more than one ability at the same time, the main effect can be clearly defined in most (Gyarmathy, 1998). In OxIPO ability-developing games, you must define at least one target ability from the set of capabilities that the game can mobilize.

The output component of the OxIPO model in development games. For OxIPO ability-developing games, the output (the player's response after information input, and followed by processing) can usually occur verbally, in writing / drawing or by performing some movement.

Based on these, the output can happen:

- Using visual modality (the player draws, writes, shows something whose sight is the key and not what the player is doing). So, if the essence of the task is to create a visually perceptible piece of work (writing, drawing, etc.) and evaluate the work, not the motion needed to produce it (which we might not have observed e.g. in a homework assignment). We will continue to treat such works as visual output for simplicity - although we add that through fine-motor skills, eye-hand coordination, device management, etc. experience can also be obtained.
- Using auditiv modality (the player claps, beats, says or sings something, the sound of which are more important than the movements which needed for these auditive responses). If a player produces a sound (an auditive stimulus) with some motion, the sound is more relevant from the developer teacher's point of view than the movement leading to it (which may not be noticeable to the observer, like in case of a tape recorder or a phone), then we are talking about auditive output.

- With a kinesthetic nature: the output may incur movement (in which case the player's movement is the point, not the view or sound of the motion, which ultimately can be regarded as visual or auditory information for the referee). Regarding movement, it is customary to distinguish between fine-motorics (actions requiring precise action, fine, coordinated movements of hands and fingers such as writing, drawing), or movements that involve high moves in body posture.

Typically, the production of visual (written, drawing) outputs assume the player's fine motoric action (writing, drawing), and auditive outputs (motion output, clapping) also assume movement. Exercising the motion output can also be used to develop the body scheme, spatial and temporal orientation, fine motorics and high motion (see Csányi, 2015 - a wealthy collection of tasks) as well as for its energetic and refreshing effect.

Uni-, multi- and intermodality in input and output components. Affolter's (1972) model of the perception development - which partly forms the theoretical background of the Sindelar program (Sedlak and Sindelar, 2005) - distinguishes three stages of the development of perception:

- Modality specific level: visual, auditory, and tactile-kinestetic information is processed separately. 
- Intermodal level: information from different detection areas is interconnected. For example, during school learning, it is essential that a learner is able to connect a page that is requested by a teacher in the context of a page number (auditive modality) and a page in a textbook (visual modality).

- Level of serial integration: the sequence of information is understood and maintained.

In the development of abilities based on the OxIPO model, the modality theme raised by Affolter in relation to perception is applied after thorough revision:

- We consider not only the input (perceptual) modalities, but the output modalities too.
- Instead of "intermodal", the word "multimodal" is used in relation to development games. Cause: The term "intermodal" refers to the perception of a person's connection to different modal stimuli, and the term "multimodal" refers to the different modality of stimuli expressed during the development game.

- We consider the modality identity or difference between the input and output.

The input / output modality has 6 possible types (the modality of the task and the requested way of responses are in brackets).

These are the following (Table 2):

Table 2: six possible types of input/output modality - task and response requested are in backets (source: Meró and Merö, 2019, Mezó and co., 2018)

\begin{tabular}{|c|c|c|c|}
\hline $\mathbf{N}$ & $\begin{array}{c}\text { Input } \\
\text { (Example) }\end{array}$ & $\begin{array}{l}\text { Output } \\
\text { (Example) }\end{array}$ & $\begin{array}{l}\text { Homogenity of input and output } \\
\text { (Example) }\end{array}$ \\
\hline 1 & $\begin{array}{c}\text { Unimodal } \\
\text { (verbal) }\end{array}$ & $\begin{array}{l}\text { Unimodal } \\
\text { (verbal) }\end{array}$ & $\begin{array}{c}\text { Homogene } \\
\text { (Tell your name!) }\end{array}$ \\
\hline 2 & $\begin{array}{l}\text { Unimodal } \\
\text { (verbal) }\end{array}$ & $\begin{array}{l}\text { Unimodal } \\
\text { (drawing) }\end{array}$ & $\begin{array}{c}\text { Heterogene } \\
\text { (Draw yourself?) }\end{array}$ \\
\hline 3 & $\begin{array}{l}\text { Unimodal } \\
\text { (verbal) }\end{array}$ & $\begin{array}{c}\text { Multimodal } \\
\text { (verbal+drawing) }\end{array}$ & $\begin{array}{c}\text { Heterogene } \\
\text { (Draw something then tell what you } \\
\text { drew!) }\end{array}$ \\
\hline 4 & $\begin{array}{c}\text { Multimodal } \\
\text { (verbal }+ \text { written) }\end{array}$ & $\begin{array}{l}\text { Unimodal } \\
\text { (drawing) }\end{array}$ & $\begin{array}{c}\text { Heterogene } \\
\text { (Read the task then draw what it } \\
\text { asks!) }\end{array}$ \\
\hline 5 & $\begin{array}{c}\text { Multimodal } \\
\text { (verbal+wvritten) }\end{array}$ & $\begin{array}{l}\text { Multimodal } \\
\text { (verbal-written) }\end{array}$ & $\begin{array}{c}\text { Homogene } \\
\text { (Read the task then write down and } \\
\text { explain your answer!) }\end{array}$ \\
\hline 6 & $\begin{array}{l}\text { Multimodal } \\
\text { (verbal+taste) }\end{array}$ & $\begin{array}{c}\text { Multimodal } \\
\text { (motional+written) }\end{array}$ & $\begin{array}{l}\text { Heterogene } \\
\text { (Close your eyes and taste the } \\
\text { contents of the two glasses. Then } \\
\text { you can open your eyes, run to the } \\
\text { board, and write the order in which } \\
\text { you tasted the flavors. How was the } \\
\text { first taste and how was the second) }\end{array}$ \\
\hline
\end{tabular}


We can difference the next possibilities from aspects of number and similarity of modality of input (=stimuli what are given by game master) and output (= observable responses of player).

Unimodal input: the information input is performed via only one channel (for example, we can use the visual input channel, when our instruction is in writing; Figure 2).

Figure 2: unimodal input (By the Authors)

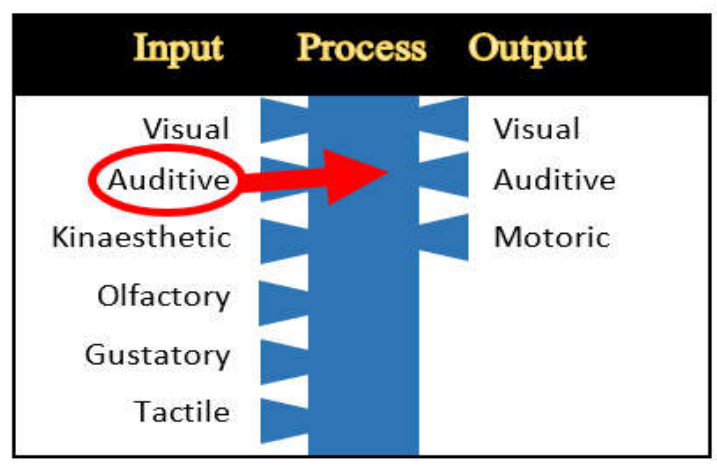

Unimodal output: information output is performed via only one channel (for example, in the visual channel when our response is a drawing; Figure 3).

Figure 3: unimodal output (By the Authors)

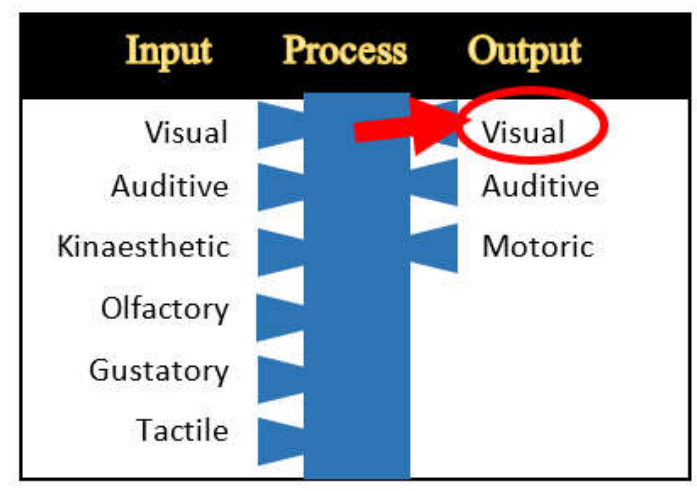

Multimodal input: the information input is executed via multiple channels (e.g., visual and auditory channels, when the assignment of tasks is done in writing and in words; Figure 4).

Figure 4: mulitmodal input (By the Authors)

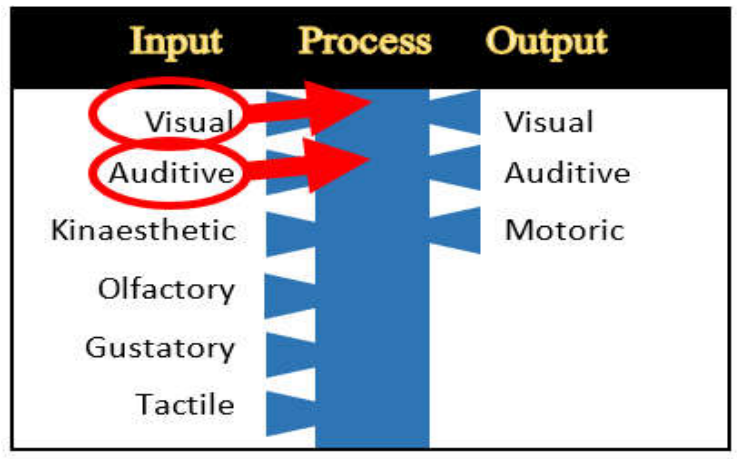

Multimodal output: the information output is performed via multiple channels (verbal and written answers are also given by the student; Figure 5).

Figure 5: mulitmodal output (By the Authors)

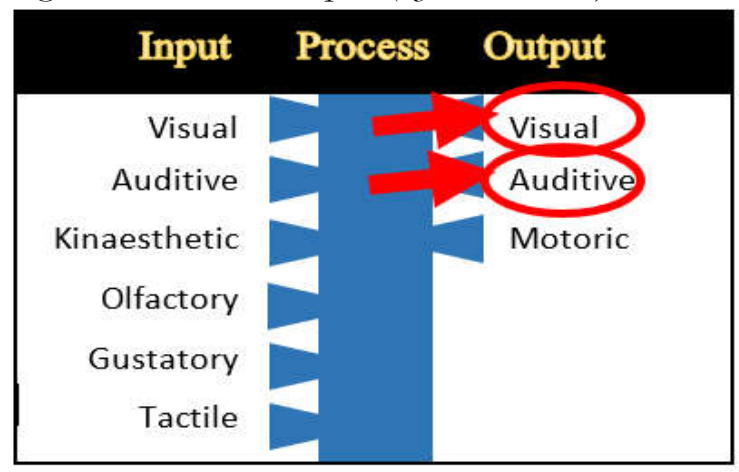

Homogeneous imput/output (I/O) modality: the input and output channels are identical (for example, auditory: verbal answer to verbal question, Figure 6).

Heterogeneous input/output (I/O) multimodality: the input and output channels are different (for example: In case of "Draw something!" instruction we give an auditive input, and we wait for a visual output; Figure 7). 
Figure 6. homogeneous input/output (I/O) modality (By the Authors)

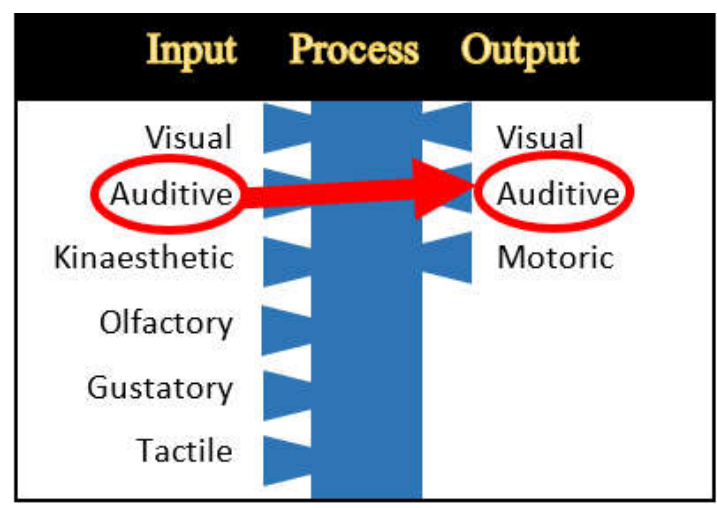

Based on these, the instruction of the exercises consists of at least three elements in OxIPO ability development games (Table 3):

- Input component: the first part of instruction defines the input modality. For example, when using auditive input, this component can be something like "Listen to what I'm saying ..."

- Process component: the second part of instruction defines the cognitive (target)ability targeted during the process. For example, the previous example can be continued in case we focus on memory: "... and remember it, note it!"

- Output component: the third part of instruction ddescribes the modality of output. Example of visual output: "Draw down what you remember!".

The organization component of the OxIPO model in development games. Regarding the organization of development games, the referee $(=$ developer pedagogue) always has the task of:

1. Choice of location, design, accessibility, safety.

2. Scheduling the timing
Figure 7: heterogeneous input/output (I/O) multimodality: (By the Authors)

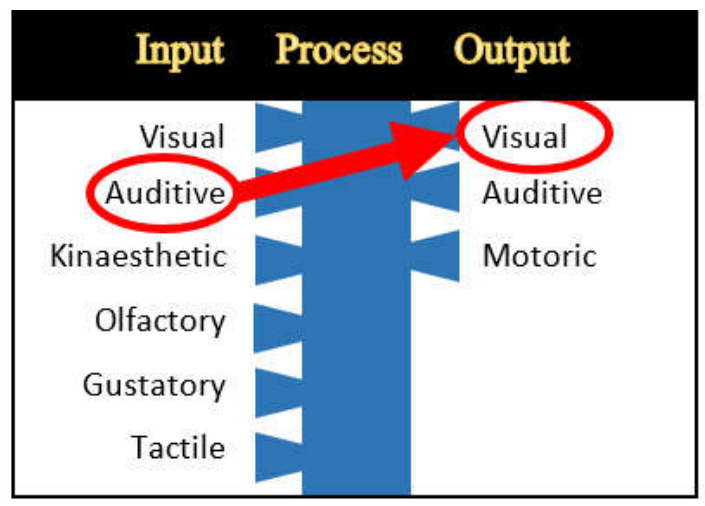

\section{Future plans}

In the future, we must prove with empirical studies, that this game collection is useable for test-ing and developing 90 independent cognitive abilities. On the other hand, we must prove that these cognitive abilities do really impact everyday life and school life and achievements.

For these aims, the authors worked out a new innovative measurement system of pupils' cognitive and non-cognitive characteristics (this innovation is a part of the EFOP-3.2.6-16-2016-00001 project of Hungarian University of Fine Arts; innovators are Ferenc Mező and Katalin Mezô). Its main characteristics are:

- Name: S.M.ART (School, Measurement, and Art)

- It contains tests, questionnaires, observation lists, and semi-structured interviews 
(the full system contains 20 different diagnostic tools).

- These are in teacher's competence.

- These can give information about pupils' cognitive and non-cognitive

- characteristics.

- The pupils are not needed to read and write during the data collection of these measurements.
- Its other features are a fast, group, cheap measurements that can be integrated (music, dance, literature and visual) art lessons (Mező és Mező, 2020a,b,c,d,e,f, Mező és tsai, 2020a,b).

The S.M.ART test-system (with handbooks and tools) can be found on the webpage of Hungarian University of Fine Arts: http://www.kiskepzo.hu/efop326/index.html

Table 3: OxIPO auxiliary board for the design of ability development games, tasks and instructions (By the Authors)

\begin{tabular}{|c|c|c|}
\hline 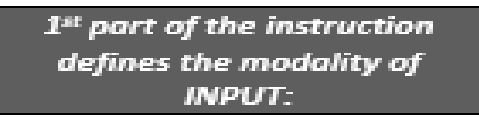 & $\begin{array}{l}2^{\text {nd }} \text { part of the instruction } \\
\text { defines the modality of } \\
\text { PROCESS: }\end{array}$ & $\begin{array}{l}3^{\text {rd }} \text { part of the instruction } \\
\text { defines the modality of } \\
\text { OUTPU: }\end{array}$ \\
\hline $\begin{array}{l}\text { Visual: } \\
\text { Look at... the color (s)! the } \\
\text { form (s)! the picture(s)! the } \\
\text { movement(s)! the sign (s)! the } \\
\text { sign(s)! the writing (s)! the } \\
\text { letter(s)! the word / words! } \\
\text { the sentence (s)! the number } \\
\text { (s)! } \\
\text { Auditive: } \\
\text { Hear to.../Listen to... the voice } \\
\text { (s)! the rhythm (s)! the melody } \\
\text { (ies)! the music (s)! the text } \\
\text { (s)! } \\
\text { Kinesthetic: } \\
\text { Perceive your body's position } \\
\text { (s)! your body part (s)! your } \\
\text { movement! } \\
\text { Olfactory: } \\
\text { Smell the scent (s)! } \\
\text { Gustatory: } \\
\text { Taste the flavour (s)! } \\
\text { Temperature: } \\
\text { Feel the temperature (s) } \\
\text { Tactile: } \\
\text { Touch ... the subject (s)! the } \\
\text { living creature (s)! } \\
\text { Other sense: } \\
\text { Fell me if you feel! } \\
\text { Feel the...! }\end{array}$ & 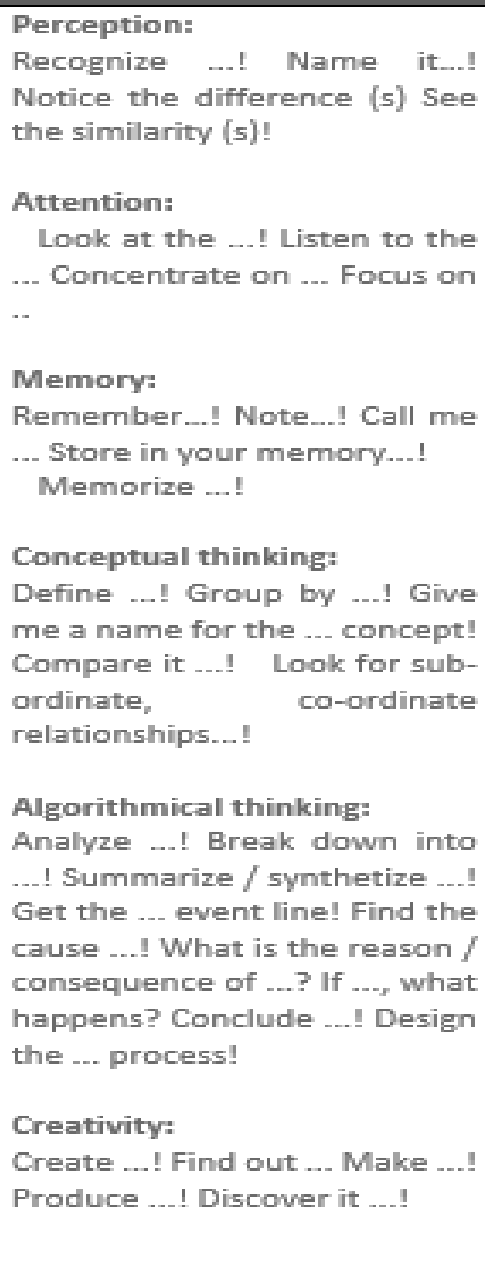 & 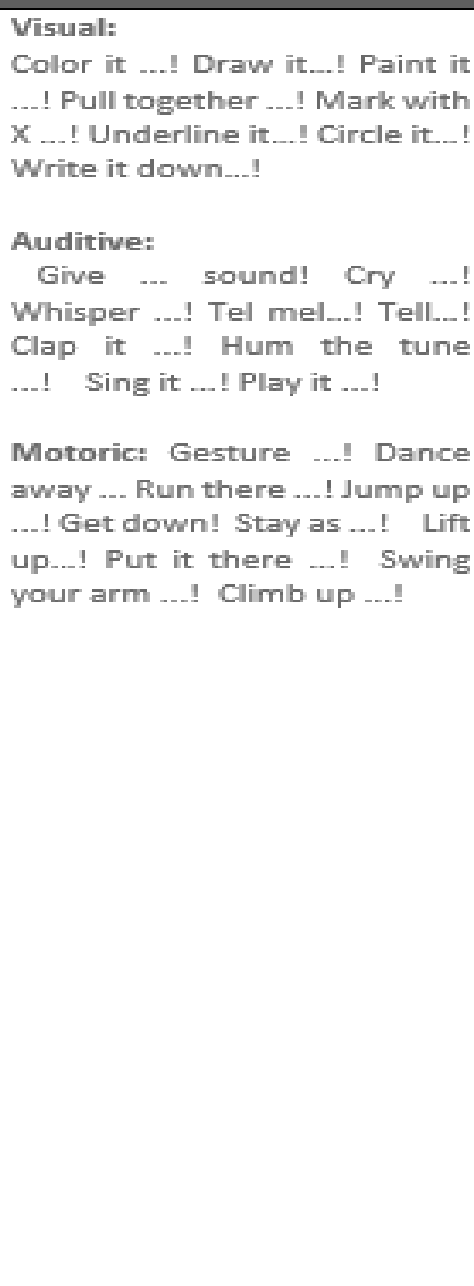 \\
\hline
\end{tabular}




\section{References}

Affolter, F. (1972). Az észlelési funkciók zavartalan és patológiás fejlődésének szempontjai. In Torda Ágnes (szerk.): Szemelvények a tanulási zavarok köréból. Nemzeti Tankönyvkiadó, Budapest. $87-$ 95

Csányi Mariann (2015): Rehabilitáció a gyakorlatban - Egyéni fejlesztési terv, Különleges Bánásmód, 1. (4), 77-100. DOI 10.18458/KB.2015.4.77

Kovácsné Bakosi Éva, Pálfi Sándor (2015): A fejlesztő játékok módszertani alapjai. Szilágyi, Barnabás; Mező, Katalin; Mező, Ferenc (szerk.). Az együttnevelés útjai. Debreceni Egyetemi Kiadó, Debrecen. 217-239.

Mező Ferenc (2002, 2004). A tanulás stratégiája. Pedellus Novitas Kft., Debrecen.

Mező Ferenc (2011). Tanulás: diagnosztikea és fejlesztés az. IPOO-modell alapján. $\mathrm{K}+\mathrm{F}$ stúdió Kft., Debrecen.

Mező Ferenc (2016). A viselkedés elemzése és fejlesztése. $\mathrm{K}+\mathrm{F}$ Stúdió Kft., Debrecen.

Mező Ferenc (2017). Fejlesžtô pedagógia - Elmélet és gyakorlati példatár a képesséffejlesztés köréból. Kocka Kör, Debrecen.

Mező Ferenc és Mező Katalin (szerk.)(2013). Képességfejlesztés - elmélet és példatár. Debreceni Egyetemi Kiadó, Debrecen.

Mező Ferenc, Mező Katalin és Mező Lilla Dóra (2018). Képességfejlesztő játékok az IPOOmodell aspektusából: a fejlesztésbe integrált diagnosztika lehetősége. Különleges Bánásmód, 4. (2.). 55-66.

Mező Katalin; Mező Ferenc (2019). Az OxIPOmodellen alapuló képességfejlesztés. In: Pálfi, Sándor (szerk.) Kora gyermekekori nevelés, család és közösségek = Early childhood education, families and communities. Didakt Kft., Debrecen. 77-86.

Mező Ferenc és Mező Katalin (2020a): S.M.ART müvészeti méröeszköz: S.M.ART-K: képrớmúvészeti foglalkozásokba integrálható viæsgálatok. Magyar Képzőművészeti Egyetem, Budapest. ISBN 978-963-7165-89-4
Mező Ferenc és Mező Katalin (2020b): S.M.ART müvészeti méröeszköz: S.M.ART-Z: zenemüvészeti foglalkozásokba integrálható vižsgálatok. Magyar Képzőművészeti Egyetem, Budapest. ISBN 978-963-7165-90-0

Mező Ferenc és Mező Katalin (2020c): S.M.ART müvészeti méróeszköz: S.M.ART-I: irodalmi foglalkozásokba integrálható vizsgálatok. Magyar Képzőmúvészeti Egyetem, Budapest. ISBN 978-963-7165-92-4

Mező Ferenc és Mező Katalin (2020d): S.M.ART müvészeti méröeszköz: S.M.ART-K: kézikönyv. Magyar Képzőművészeti Egyetem, Budapest. ISBN 978-963-7165-93-1

Mező Ferenc és Mező Katalin (2020e): S.M.ART müvészeti méröeszköz: S.M.ART-Z: kézikönyv. Magyar Képzőművészeti Egyetem, Budapest. ISBN 978-963-7165-94-8

Mező Ferenc és Mező Katalin (2020f): S.M.ART müvészeti méröesžöz. S.M.ART-I: kézilkönyv. Magyar Képzőművészeti Egyetem, Budapest. ISBN 978-963-7165-96-2

Mező Ferenc, Mező Katalin és Mező Kristóf Szíriusz (2020a): S.M.ART müvészeti méróesžö̈: S.M.ART-T: táncmüvészeti foglalkozásokeba integrálható vizsgálatok. Magyar Képzőmunvészeti Egyetem, Budapest. ISBN 978-963-7165-91-7

Mező Ferenc, Mező Katalin és Mező Kristóf Szíriusz (2020b): S.M.ART müvészeti méröeszköz: S.M.ART-T: kézikönyv. Magyar Képzőművészeti Egyetem, Budapest. ISBN 978-963-7165-95-5

Sedlak Franz, Sindelar Brigitta (2005). "De jó már én is tudom". ELTE Bárczi Gusztáv Gyógypedagógiai Kar, Budapest.

Sindelar, B. (1994). Teilleistungsschwächen (Tanulási zavarok) Eigenverlag, Wien. 